Article

\title{
The Loss of the Popular: Reconstructing Fifty Years of Studying Popular Culture
}

\author{
Joke Hermes ${ }^{1, *}$ and Jan Teurlings ${ }^{2}$ \\ ${ }^{1}$ Research Group Creative Business, Inholland University, The Netherlands; E-Mail: joke.hermes@inholland.nl \\ 2 Department of Media Studies, University of Amsterdam, The Netherlands; E-Mail: j.a.teurlings@uva.nl \\ * Corresponding author
}

Submitted: 26 February 2021 | Accepted: 13 April 2021 | Published: 13 September 2021

\begin{abstract}
This article starts from the observation that popular culture resides in a contradictory space. On the one hand it seems to be thriving, in that the range of media objects that were previously studied under the rubric of popular culture has certainly expanded. Yet, cultural studies scholars rarely study these media objects as popular culture. Instead, concerns about immaterial labor, about the manipulation of voting behavior and public opinion, about filter bubbles and societal polarization, and about populist authoritarianism, determine the dominant frames with which the contemporary media environment is approached. This article aims to trace how this change has come to pass over the last 50 years. It argues that changes in the media environment are important, but also that cultural studies as an institutionalizing interdisciplinary project has changed. It identifies "the moment of popular culture" as a relatively short-lived but epoch-defining moment in cultural studies. This moment was subsequently displaced by a set of related yet different theoretical problematics that gradually moved the study of popular culture away from the popular. These displacements are: the hollowing out of the notion of the popular, as signaled early on by Meaghan Morris' article "The Banality of Cultural Studies" in 1988; the institutionalization of cultural studies; the rise of the governmentality approach and a growing engagement with affect theory.
\end{abstract}

\section{Keywords}

affect theory; banality; cultural studies; Foucault; governmentality; media environment; popular culture; the popular

\section{Issue}

This article is part of the issue "From Sony's Walkman to RuPaul's Drag Race: A Landscape of Contemporary Popular Culture" edited by Tonny Krijnen (Erasmus University Rotterdam, The Netherlands), Frederik Dhaenens (Ghent University, Belgium) and Niall Brennan (Fairfield University, USA).

(C) 2021 by the authors; licensee Cogitatio (Lisbon, Portugal). This article is licensed under a Creative Commons Attribution 4.0 International License (CC BY).

\section{Introduction}

“People griping about nonwhite actors in Bridgerton but not fussing about the Duke wearing riding boots to a ball?! Riding boots!" (Fredericks, 2020). The above is a tweet about the Netflix series Bridgerton. It makes lighthearted fun of others taking a popular television series way too seriously. Or perhaps of mistaking popular culture for always being about something else: Anti-racist activism and historical accuracy are suggested to be equally important issues. In jest, the tweet says that we might want to return to popular culture as popular cul- ture. That is exactly our starting point in this joint article. We participated in an online roundtable on "The Power of the Popular," organized by IAMCR's Popular Culture Working Group. The theme of the discussion was the status of popular culture in the 2020s. Even though we approached the question from different angles, we found ourselves in agreement that it seemed popular culture is no longer studied as popular culture. By this we meant that studies of the popular no longer invoke the notion of popular culture, even when they use the term. To be sure, media and cultural studies scholars continue to study phenomena that would have been considered 
popular culture in the 1980s. On the surface, it would therefore seem that we never really left the terrain of the popular. When analyzing, say, the way Twitter controversies shape public discourse, it is clear a 1980s scholar, magically transported to 2021, would have no trouble approaching Twitter as a cultural forum (Newcomb \& Hirsch, 1983) where different views and parts of society meet and interact. That same 1980s scholar would also approach Twitter as neither entirely top-down nor entirely bottom-up, operating instead somewhere in between the abstract forces of the cultural industries while generating and requiring activity and enthusiasm "from below." Twitter comments are neither high culture nor the kind of authentic folk culture associated with premodernity. All of this to say that yes, Twitter can be considered-is, actually-popular culture.

However, we do not study Twitter as popular culture. Instead, we look at it and other social media platforms as a place where the free labor of users is exploited (Fuchs, 2010; Terranova, 2000), or as a powerful advertisement platform that manipulates voting behavior through targeted advertising (Tufekci, 2014). We look at it as a network that can manipulate public opinion through the creation of botnets (Bastos \& Mercea, 2019), a place where filter bubbles reinforce existing opinions (Pariser, 2011), or as a platform that allows populist leaders to bypass the traditional media of old (Enli, 2017). It seems popular culture is studied as a means to study something we are tempted to designate a bit sarcastically as "more important." An example is the recent Popular Culture and the Civic Imagination: Case Studies of Creative Social Change, edited by Jenkins et al. (2020). Notably and commendably, Jenkins also spends his time on The Civic Imagination Project, "to explore ways to inspire creative collaborations within communities as they work together to identify shared values and visions for the future," taking a step away from being a popular culture scholar to being a community worker and activist (Jenkins, 2021).

What we see in recent work like this is that, even though the words "popular culture" figure prominently, the entire conceptual framework that came with "popular culture" and "the popular" has been relegated to the background: the topological distinctions between elite, mass, folk, and popular culture; the culturalist insight that popular culture is actively produced; the Gramscian idea that popular culture is the place where common sense is produced and formed. Notwithstanding exceptions, what remains is a "fun" object ("popular culture") without the conceptual framework that tied everyday practices of meaning making to engaged research of power structures. Or a zone of exploitation, subjection or exclusion, of course.

This article is an attempt to trace how that change occurred. In answering that question, we focus on subsequent transformations of the cultural studies project, arguably the interdisciplinary domain that introduced and disseminated the term. Our point of reference here is what came to be known as cultural studies in the $1980 \mathrm{~s}$ and 1990s and originated in Britain (focused on class and ideology), Australia (work on policy, governmentality, and the creative industries), and the US (fans, genres, and affect). While less easily identified, it originated elsewhere too, for instance as studies of youth culture and music in Scandinavia. We are less interested in work that approaches popular culture as folk culture (as in ethnologist approaches, e.g., at German universities) or uses literary methods. The cultural studies of the $1980 \mathrm{~s}$ and 1990s, published in Cultural Studies and, by the end of the decade, in the International Journal of Cultural Studies, and the European Journal of Cultural Studies, understood popular culture as a linking pin. It connected what Williams called a structure of feeling with concrete and identifiable cultural texts. Popular culture thus gave access to the hearts and minds of "ordinary people," to what connected those who did not have automatic access to the public space of politics and information. In entertainment, politics and the popular were understood to merge.

Cultural studies' modes of political engagement changed, as did the popular culture objects that were (and are) studied: from soap opera to reality TV, to games, and social media today. This article traces a genealogy of the debate on popular culture, in the precise Foucauldian sense of the word, namely as "a history of the present," one that explains how the present moment came into being (Foucault, 1977, p. 31). From a vibrant, engaged form of scholarship emerged something completely different, in which recognition of the merits of popular culture-understood as texts-in-action, the text/style/object-related practices that are energized by the shared use of music, TV series, clothes-have been drastically altered and perhaps even been lost. Even though the focus of this article is on changes in scholarship, and especially on the way scholars have conceptually approached popular culture objects, it is worth pointing out that as a field of objects that energize and connect, popular culture itself has also changed, for various technological, economic, and political reasons.

The merging of popular texts and politics that is characteristic of cultural studies work, is prefigured in Hall and Whannell's collection The Popular Arts (1964) and Fiske and Hartley's Reading Television (1978). Both books depend significantly on semiotics, where later work merged semiotics and Marxism with an ethnographic approach. They need to be credited with making well-read "low cultural" texts worthy of serious academic attention. Popular television as in police series, westerns, lan Fleming's James Bond novels, jazz, and advertising are all discussed. "Popular culture" itself, as a label, is put to new use to undo the ideological force of the high-low culture distinction and expands the much more restrictive use of the term by historians such as Burke (1978/2009). The key element that changed is that the commercial nature of these widely used and appreciated texts no longer counted against taking them seriously. 
Early work on popular culture in cultural studies, in its enthusiasm to defend the relevance and importance of this new domain of critical work, developed a penchant to cast different kinds of everyday, often media-related practices as transgressive and resisting dominant culture. These claims may not always have been entirely convincing. A certain level of "optimism of the will" was required by researchers and readers, but it was not an impossible task. There were enough links to progressive ideas in the popular culture of the 1970s-1990s to at least warrant the option of reading popular cultural practices as progressive (via oppositional or aberrant decoding). In today's context that feels more problematic. Gamers out to bully women journalists (Seymour, 2016), conspiracy theories, the deep commercialization of making your own online influencer video: All of these examples either do not read as a political agenda, or when they do, do so as a deeply exclusionary and right-wing one. The occasional hopeful reading of e.g., RuPaul's Drag Race, as an emancipatory moment that queers gender conventions and offers a highly diverse range of ethnicities in competitors on this television show, also points to host RuPaul's deeply neoliberal convictions. Fans and viewers combine their love of the show with the criticism that it discriminates against darker-skinned queens and trans women as contenders (Hermes \& Kardolus, 2019). All of these changes within popular culture and in its users as well go a long way in explaining "the loss of the popular." However, at least equally important are a series of paradigm shifts that gradually shifted the object of cultural studies.

Before proceeding to an overview of these paradigm shifts, a word of clarification. The expression "loss of the popular" might be interpreted as a story of betrayala once vibrant approach was betrayed by subsequent scholarship-and a call to return to the origins. This is emphatically not the intention behind our argument. Each of the changes we identify below responded to earlier problems and offered valuable ways forward. It was, in other words, not a question of betrayal but of scholarly work responding to paradigmatic deficiencies and societal changes (and in some instances, changing political priorities). But the net effect of this work of advancement has been a gradual redefinition and reorientation of the field, and it is the latter that we are trying to capture with the expression "loss of the popular."

\section{2. "This Has Gone Too Far"}

The first movement away from studying popular culture through the lens of the popular did not take place as a result of a paradigm shift, but rather as the result of unease with the direction the study of popular culture had taken. It is easy to forget how soon this sense of unease emerged. Already in 1988-merely one year after Fiske published Television Culture (Fiske, 1987)Meaghan Morris published her Banality in Cultural Studies essay, which became the programmatic text in the anti-celebratory approach to popular culture:

I get the feeling that somewhere in some English publisher's vault there is a master-disk from which thousands of versions of the same article about pleasure, resistance, and the politics of consumption are being run off under different names with minor variations. (Morris, 1988, p. 15)

Morris' critique entailed more than the complaint that the celebratory takes on popular culture were repetitive and decontextualized. She also argued that the use of interview material amounted to little more than a "vox pop" technique, in which the interviewer becomes the spokesperson (and thus privileged interpreter) for what the interviewee actually means: "The people is a voice, or a figure of a voice, cited in a discourse of exegesis" (1988, p. 16, emphasis in the original). Or, in one of the harsher judgements in the essay, "the people are... the textually delegated, allegorical emblem of the critics' own activity" (p. 17). Thus, instead of giving a voice to "the people," the scholars of popular culture were depicted as having become narcissistic ventriloquists, who make ordinary people utter the words they want them to speak. The result was a left populism that was mechanically transposed on any given situation and lost its critical bite.

The loss of critical purchase was also at the center of McGuigan's book-length critique Cultural Populism (1992). In a recent interview he recounts the context in which he intervened:

In the 1980s, interpretation of the culture of "ordinary people" in cultural and media studies had become peculiarly reverential and even celebratory.... had myself gone along with the rather more positive estimation of contemporary popular culture until the point-probably when reading John Fiskewhen I thought, come on, this has gone too far! Critical judgement had been abandoned too easily. (Moran \& McGuigan, 2020, pp. 1005-1006)

McGuigan did not challenge the importance of studying popular culture: He remained attached to the idea that "the cultures of ordinary people are of paramount importance" (Moran \& McGuigan, 2020, p. 1007). He considered the knee-jerk celebration of popular culture, however, an undesirable evolution of an otherwise correct idea that popular culture was a terrain not to be neglected by politically engaged intellectuals. In this sense, these early criticisms of the cultural studies project on popular culture represents a corrective moment, more interested in a return to the source than in abandoning it: not a loss of the popular but a reappraisal of it.

It needs to be mentioned that the corrective moment came with its own set of limitations. The work of John Fiske conveniently served as a shorthand for all of 
cultural studies, which does not do justice to the wide variety of nuanced empirical work that was dismissed as celebratory and populist. Neither did his critics give John Fiske any credit for the wave of scholarly enthusiasm and inspiration that his work undeniably generated, or the complexity of his reasoning.

\section{Institutionalization: From Popular Culture to Audience Research}

Looking back, the earliest engagement with popular culture from a cultural studies perspective we became acquainted with, would be work at the Centre for Contemporary Cultural Studies (CCCS) in Birmingham. There is the famous Resistance Through Rituals (Hall \& Jefferson, 1975) collection on youth culture and how its rebellion against established class culture is afforded by making wayward use of consumer culture. The attraction of the CCCS books and earlier stenciled papers lies at least in part in the surprising tolerance for consumption and what could easily be demeaned as trivial pastimes and interests, given the keen interest in Marxist philosophy at the CCCS.

At the CCCS, the importance of everyday meaning making and of popular culture was never a given, nor was their significance ever underestimated. Rather, both were felt to be in need of theoretical understanding. With regard to conceptualizing popular culture, Gramsci's writing (1971) on civil society, common sense, and organic intellectuals was important, as was Althusser's work (1971). Althusser offered ideology and recognition as concepts, while Gramsci solved Althusser's problematic distinction between science and ideology, as well as the associated notion of false consciousness. He also insisted on common sense as fragmented, disjointed, and contradictory (and thus open to change). In an essay originally written in 1977, Hall et al. explicitly bring both arguments together: "Because Gramsci does not work with a true/false consciousness or science/ideology model his thinking is directed towards the contradictory possibilities within spontaneous, non-systematised forms of thinking and action" (2007, p. 284). Allowing for contradiction might well be the single most important contribution to critical thinking that made studying popular culture at all possible.

It allows us to understand how exceptional a collection Resistance Through Rituals is in combining a Marxist perspective, extensive ethnographic description, and a somewhat romantic rendering of the spirit of independence amongst young people. Together with Hebdige's slightly later Subculture: The Meaning of Style (1979), Resistance established the political significance of youth culture. Subculture: The Meaning of Style in turn established the "reading" of culture as a valid method of cultural research that Meaghan Morris would be so very critical of ten years later. Its implied method is ethnographic, even if Hebdige does not offer a methodological account. Like Marxism, feminism is an important source of inspiration for the CCCS researchers. It allows for a different type of argumentation, as becomes clear from the work of the CCCS Women's Studies Group in Women Take Issue (1978). It is far less celebratory of popular culture and resistance against dominant culture than the work of the men is.

The famous example of Angela McRobbie's chapter in Women Take Issue, in which she wrote about talking with girls about their bedrooms, provides a link to popular music but also to acquiescence with patriarchal rules. Both returned, popular music and women's popular culture, in work undertaken in the US. American media and cultural studies scholar Larry Grossberg wrote about popular music and resistance. He would also introduce the notion of "affect," which was to provide a new direction for cultural analysis (defined broadly) by the end of the 1990s. Secondly, unaware of the work in Birmingham, UK, Janice Radway studied romance reading in the US, following a remarkably similar logic to the CCCS Women's group (Radway, 1984). She, too, understood women's reading of romances as only a temporary bid for freedom that at the same time rewrites dominant ideology. Romance reading rebuilds masculinity as both caring and spectacular, as part of the fantasy shared by novels and readers.

In the early 1980s, studying popular culture was a political act in itself. Authors engaged with social power relations and subordinate groups by doing research among different groups of popular culture users. Taking the perspective of its users (rather than that of popular culture's critics) was commonly referred to as "ethnographically inspired." Whether it was Ang's work on Dallas (1985), the prime time soap series, Radway's work on romances (1984), or Morley's on television viewing $(1980,1986)$. Their seminal texts all start from the experiences of actual viewers and readers, who talk about cultural texts that are not deemed very worthy. Their work countered established notions about the utter lack of quality in popular entertainment that John Hartley dates back to the 19th-century tenets of class culture. It also countered how these tenets were upheld by what he calls the knowledge class: schoolmasters in the 19th century, intellectuals of the "fear" school in the late 20th century (Hartley, 1999, pp. 124, 133-134). While Morley, Ang, and Radway offered a combination of ethnographic method and engagement with texts, the method part of their work was not what attracted others to this new field of study. They were read as alternatives to the dismissive and pessimist "mass culture" paradigm (Jensen, 1990) and fed a gleeful sense that consumer culture might not be all bad.

Notably, the double political agenda their work served was a feminist one rather than the Marxist one in the earlier work at the CCCS. Ang (1985) suggested that melodrama's tragic structure of feeling allows for emotional realism, a new term with which to approach how media texts become meaningful. Rather than reduce reactions to the soap series as sentimental drivel, and 
a typical example of women's culture, Ang offered an account of the fantasy work involved in engaging with media texts. Morley (1986) focused on both class and gender in his work, carefully noting how masculinity in the home is a mode of power. While attacked for interpreting romance reading as a form of proto-feminism, Radway (1984) showed popular culture to be a space of negotiation that temporarily rewrote patriarchal rule and ideology, i.e., that it is women's task to care for others emotionally, and not men's.

While Ang, Morley, and Radway are seen as media and cultural studies scholars, it is earlier work at the CCCS that established academics studying popular culture as "organic intellectuals" (Fernández Castro, 2017). "The popular" and "common sense" had come to be considered valuable categories. Morris correctly identified the sleight of hand taking place, from the voice of the people to the academic as a mouthpiece. She was too irritated, however, to see how ethnographic insight had simultaneously come to be valued in cultural studies, stemming from academics' personal engagement with specific popular cultural texts as well as with a strong wish for non-patronizing forms of research. As Hoggart said when talking about literacy in 1998:

You see you're always torn if you come from my kind of background....Perhaps excessively, you don't want to appear to patronize. You want to understand better. So I wanted to avoid two things in The Uses of Literacy. One was the dismissal of working-class culture as though it was nothing, was worthless or crude. And the other was sentimental acceptance, which is just as bad. (Gibson \& Hartley, 1998, p. 14)

The early "organic intellectuals" cared about specific texts and their users. As the focus on media use grew stronger, there was a move away from "the popular" as such while criticism of the new popular culture research intensified. Curran criticized what he called "the new revisionism" in mass communication research for its lack of historical awareness of earlier pluralist communication research that held similar tenets regarding audiences' appreciation of media texts (1990, p. 158). When Winlow and Hall (2007) reviewed the second edition of Resistance Through Rituals a decade and a half later, they reiterated a sense of disappointment that has come to haunt cultural studies:

We did expect Hall and Jefferson to deal directly with the main flaw of the CCCS's work, which for many of its critics is the assumption that youth subcultures have the irrepressible ability to avoid the compulsions and seductions of the consumer culture they inhabit, always nimbly moving beyond its chain of signification and processes of identification to fashion their own meanings and identities as methods of resisting the dominant order. (p. 395)
While early popular culture research presented a happy and irreverent mix of disciplinary backgrounds, ranging from the literary to criminology, sociology, political economy, and psychoanalysis, the 1990s proved a period of attrition and disciplining of an unruly field. For Curran (1990), the fact that researchers did not understand their compliance with consumer culture, pointed to how the new cultural studies work was really just a new chapter in the tradition of mass communication research. Winlow and Hall (2007) spoke of post-war sociology and a similar failure not to take mass cultural and consumerist manipulation into account. Others felt that the link made to ethnography is erroneous. Although the new audience researchers might well have been inspired by how critical anthropologists took Geertz's "thick description" further to question the power relation between researcher and researched (Clifford \& Marcus, 1986; Geertz, 1973), they were not actually doing fieldwork. Often, the power of popular culture was such that researchers felt deeply familiar with what they studied and used personal experience rather than long interviews or participant observation in a more formal sense. This is not incommensurable with ethnography (Hammersley \& Atkinson, 1998), but it differed greatly from the lengthy fieldwork that, exceptionally, Gillespie (1995) and Thornton (1995) did conduct.

Over two decades, work that started from engagement with forms of culture that were presumed to be worthless, brought about the revaluation of "the popular" and popular culture, and then again lost the claim of transcendent value in popular culture as a phenomenon in and of itself. Neither Ang nor Radway understood romances or melodrama as in themselves empowering, but they did appreciate how these particular texts allowed audiences to use their agency and imagination to make them empowering. Ten years later, neither Gray (1992), or Gillespie (1995), nor Hermes (1995) understood the video recorder, television, or women's magazines as "prime movers." In the first instance, their interest was in the audiences they studied. How specific (sub)cultural forms inspire audience members was to be culled from how informants talk about their lives and media preferences rather than from the media texts or practices themselves. Media texts and technologies were credited with providing instances of resistance. Gray, for instance, noted how her informants explained their complicated cookers to her when talking about household technologies, but claimed they could not program the family VCR. A case of calculated ignorance, she argued: Not knowing how to do this meant one chore less on their plates. However telling, this was a minor countermove compared to the much grander claim made by Fiske for popular cultural texts. The shift away from the "power of the popular" was mirrored in a much stronger emphasis on method: Cultural studies was no longer a free space in academia that attracted radical thought. While all of these newer authors related their work to everyday practices of meaning making and the power 
relations that shape these practices, they were more accurately labelled as politically engaged than as radicals or organic intellectuals.

In another decade, "aca-fans" will reclaim free space and, much to the amazement of outsiders, such subjects as "Buffy studies" become part of the academic curriculum (Hills, 2002). Here a different logic returns us to popular culture as text where unexpected discoveries can be made. Here, too, the operative suggestion is that the gap between literature and pulp is not as wide as is believed. In this case, it leads to the emancipation of exceptional texts and not their users, and while it broadens what may count as "high culture," it leaves the distinction between high and low culture intact. Otherwise, popular culture studies will mostly turn into audience studies.

\section{The Governmental Turn}

The influence of governmentality studies presents a second decisive shift away from popular culture (even though, as we will see, it did not abandon the notion entirely, but instead reinterprets it by linking it to its strategic use in the wider field of culture). The influence of governmentality studies came rather late, considering the long-standing influence of Foucault on cultural studies. The focus initially was very much on Foucault's earlier work on discourse (Foucault, 1970, 1972). When his later work on power/knowledge, governmentality, and practices of the self was used, it was interpreted in such a way that it always led back to discourse. Hall's (1997) chapter in the Open University textbook Representation: Cultural Representations and Signifying Practices is a good example of this tendency to "discursify" Foucault. This changed around the 2000s, when the exhaustion of the Gramscian influence on cultural studies opened up a space for reinterpreting Foucault's work. The concept that generated the most scholarly enthusiasm was governmentality. This brought a radically different approach to culture, a paradigm shift that was less interested in conceiving culture as the site of the creation of common sense, than as a field crisscrossed by strategic power relations.

A cursory glance through the table of contents of the 2003 collection Foucault, Cultural Studies, and Governmentality, a fairly typical selection of the work being conducted under the rubric of governmentality at the time, illustrates this new orientation of culture towards strategy. There is an article on how new communication technologies have been strategically deployed in order to reconfigure the home along neoliberal lines (Hay, 2003). Coffey (2003) offers an analysis of the role of museums in the reconfiguration of Mexican society towards neoliberalism. King (2003) analyzes the rhetoric of cancer survivorship as embodied in initiatives like "Race for the Cure" and examines how such consciousness cum fundraising events redefine citizenship away from the State and towards individual ethical notions. As diverse as these analyses might be, they all approach cultural phenomena as strategically deployed in pursuit of some higher good, usually involving some large-scale but low-intensity transformation of society. In this sense, the governmentality approach to culture represented a return to earlier strands of sociological analysis that stressed the instrumentalist character of cultural goods (e.g., Packard's Hidden Persuaders, 1957; but also to some of the work of Bourdieu that stresses the role of symbolic goods in establishing and maintaining different social positions, e.g., Bourdieu, 1980).

Two observations are worth making here. First, almost unnoticed, the governmentality approach to culture eliminated the adjective popular from its conceptual apparatus. (It is worth noting, in this context, that Tony Bennett's (2003) contribution to the above collection is simply called "Culture and Governmentality"). Read positively, this meant that cultural studies widened its scope to also include phenomena that were previously considered to be "high culture." Yet, more often than not, this also had the consequence that the entire notion of the popular was evacuated from the discipline. To be sure, governmentality scholars still scrutinized popular culture objects, ranging from computer games like Civilization (Miklaucic, 2003) to reality TV shows like Judge Judy (Ouellette, 2004), but they did so without invoking the popular.

The evolution of Tony Bennett's work is a good example of this switch away from the popular towards the wider field of culture. His earlier work was heavily invested in the notion of the popular, e.g., in his writing about James Bond as a popular hero (Bennett, $1982,1986)$. But by the early 1990s he had made the switch away from the popular to study one of those classic loci of high culture: The museum, which he analyzed from a governmental point-of-view (Bennett, 1995). The series of essays gathered in Culture: A Reformer's Science (Bennett, 1998) are the culmination and further theorization of how the governmental turn impacted cultural studies' understanding of culture.

This does not mean that the notion of popular culture was abandoned in its entirety within governmentality studies, even though it was given a much diminished and certainly much less prominent place. True to form, governmentality studies at times invoked the opposition between high and low culture, but only to the extent that the difference was strategically deployed by those wanting to intervene in a social field. In Bennett's words:

Rather... than speaking of a contest of high culture versus low culture, the logic of culture, viewed governmentally, organises a means for high culture to reach into low culture in order to provide a route from one set of norms for conduct to another. $(1998$, p. 79)

Consequently, if-and this is a big if because occasions were scarce-governmentality scholars used the term popular culture, it was always from the viewpoint of how the notion was strategically deployed. 


\section{Affect Theory}

The move towards affect theory constitutes the final and definitive turn away from earlier efforts to understand popular culture for its own sake. While not named as such, affect was always part of studying popular culture as a political moment. Ang (1985) traced an intricate relationship between the melodramatic text (and its tragic structure of feeling that defines happiness as always transient and short-lived) and the emotional realism it affords. This ultimately revolved around the kind of energy soap opera offers its viewer: It seems to be a kind of warmth, a feeling of recognition and being recognized. That feeling, however, was couched not in terms of affect but in terms of ideology-an Althusserian rendering of the power of television as ideological state apparatus. Likewise, when Walkerdine (1986) wrote about watching Rocky II (the movie) with the Cole family, she pointed to how the film offers a fantasy of transformation, drawing together the text, psychoanalytical insight, and theorization of identity and subjectivity. The actual popular text is crucial to the unfolding psychic processes. Psychoanalysis, however, is not an approach that is much favored in cultural studies. As a theoretical apparatus it goes against the radical contextualization and Foucauldian understanding of subjectivity that is enthusiastically taken up by the field. Psychoanalysis' association with textualist approaches in film studies has not helped. Nevertheless, in analyses like Ang's and Walkerdine's, there is an untheorized (or at the very least differently theorized) notion of affect at work.

Discussion of affect as such emerged in cultural studies in the mid-1990s to fill a void. When Grossberg spoke of affective sensibility in relation to music fandom (1992), he used it to critically intervene in a discussion of identity and representation that felt too mechanical to him. According to Grossberg, affect is subjective feeling, which "gives 'color,' 'tone' or 'texture' to our experiences" (1992, p. 57). He used the concept of affective sensibility to think identity outside of modernist and essentialist parameters, as historically and culturally constructed, as fluid and fed by (popular) culture. As a term, affect locates the "doing of popular culture" (rather than popular culture as text) between subjects by following in Spinoza's footsteps; it aims to recognize energy and change in "being affected." While "emotion" is used to refer to the social performance of feelings and sensations, affect refers to the power of moments of connection, whether positively or negatively (Wetherell, 2012). While arguably this could tie in with engaging with the popular to understand its power, this is not what happened.

A 1999 article by Ahmed illustrates this perfectly. Just before Ahmed's work turned to affect, she wrote about "becoming" by focusing on how texts interpellate readers and construct them in doing so-which as a reader we may also resist. Her mode of analysis was to read popular texts against philosophical "master texts":
It is my position that a close and critical reading of master-texts such as $A$ Thousand Plateaus is of fundamental importance to Cultural Studies. This is not because I think we should keep a canonical narrative in place of the production of (high) theory. Rather, we need to attend closely to texts which have been read as originary and as charting a field. In the case of $A$ Thousand Plateaus, the critical appropriation of models of becoming, bodies without organs, bodies as machines and desire as positivity, all mark its powerful dissemination in cultural theory. (Ahmed, 1999, p. 49)

The crucial text here is the philosophical one. The retelling of the narrative of Dances With Wolves, the 1990s movie, was used as ammunition against it. Ahmed was not interested in its appeal as popular culture, she was interested in the homology between the two (very different) texts that allowed her to develop what reading "skeptically, critically, and closely" as a feminist (1999, p. 49) might mean in relation to engagement and the power of phantasy, and against essentialized notions of identity. Much can be recognized here, but not in any known configuration of what was previously known as "doing cultural studies." Partly it is Ahmed's unique approach. Equally, it was a sign of the times that we had moved far away from the exhilaration and pleasure early cultural studies found in subcultures and youth culture and in popular entertainment.

\section{Conclusion}

While cultural studies stopped studying popular culture in order to understand "the popular" and started using it, among other things, as a means to confront high theory, neoliberal politics was consolidating. Initiated in the Western world by politicians such as Thatcher, Reagan, and Kohl, in the 1990s neoliberalism became part of British Labour's creative industries policy (Hewison, 2014). Culture, regardless of its provenance, was felt to be an "expedient" for all sorts of policy initiatives and governmentality in general (Yudice, 2004). The broad field of media and cultural studies keenly felt that it needed to turn away from what was now deemed to be too naive an approach to mediated culture. It did not help that the new reality genres that offered a public presence to non-professionals, or "ordinary people," and then the new digital platforms that allowed for amateur production, after a brief moment of anarchist hope in the late 1990s, could be seen to close down rather than open multiple identity formation (Lovink, 2002, 2012; Ytreberg, 2004). To understand the politics of the new media culture as allowing for broad fantasies of new selves and different worlds, felt like a small part of a troubling and much larger whole. There were exceptions, of course, that recognized the political power in media as information and in the pleasure of cosplay (Andeweg, 2017; Fox \& Ralston, 2016; Gn, 2011) but the moment of "the popular" was past. 
Today, when popular culture is referenced in the hybrid field that includes cultural studies but also sociology, popular culture and the popular have become part of a research tradition, as in John Storey's work, or props for quite different arguments. When Wood and Skeggs write about reality TV, they discuss class and gender (Skeggs et al., 2008; Storey, 2018; Wood, 2017). When Littler makes her case against meritocracy and unveils it as neoliberalism at work, she references the ultra-rich as they populate TV programs and popular figures such as the "mumpreneur" (Littler, 2018). When Gloria Wekker deconstructs the politics of race in the Netherlands, the yearly Sinterklaas festivities and its caricatural Petes in blackface serve as an example of popular culture as a deeply conservative and exclusionary force (Wekker, 2016).

It is well possible that, had Stallybrass and White (1986) come across Sinterklaas when writing their Politics and Poetics of Transgression, they would have interpreted the Petes in blackface in terms of carnival and exhilaration. Referencing medieval examples, they would have cautioned that these were raucous and uncouth times that did not particularly score well on inclusion or emancipation. In as far as the popular has carnivalesque traits, Stallybrass and White might well have argued that these have to do with temporarily stepping out of line, of suspending the normal order and turning power relations upside down. That contemporary scholars approach such popular energies with distrust has very sound political reasons in times when QAnon believers storm the US Capitol. In the current conjuncture, it seems that the Right is simply better at reading and using Gramsci. Cultural studies, on the contrary, seems to have lost its sense of how texts might energize and produce collectivity and utopian connections. Of course, cultural studies has also gained critical awareness through its understanding of governmentality, and through its theorization of affect and how the senses are involved in processes of meaning making.

What this overview has tried to show is that the "moment of popular culture" was a relatively short-lived but highly influential, foundational moment in the history of cultural studies. This popular moment was subsequently displaced by a set of related yet different theoretical problematics, that gradually moved the study of popular culture away from the popular, in some instances even getting rid of the adjective in its entirety. Each of these mutations was caused by the interlocking of changing mediatic and political environments, changing political engagements, and changing scholarly views. Consolidation of the move to audience studies was as much a response to changing media technologies as it was an attempt to attenuate and empirically ground some of the more grandiose claims made in the 1980s. The governmental approach argued that an exclusive focus on popular culture blinded one to the strategic deployment of culture in the wider sense. In addition, it was inspired by the belief that cultural studies scholars should engage in policy debates. Affect theory was both an attempt to take the discipline away from an exclusive focus on discourse, meaning, and ideology, and the result of the belief that popular texts are in need of analysis but do not require any defense against their detractors. And the recent, more critical work with which we ended the previous section, no longer sees a utopian impulse in the pleasures and enthusiasm generated by popular culture, focusing instead on its reactionary energies, its increasing commodification and racist lineages.

What we have gained is a shared understanding that popular culture is a key site for the production and reproduction of hegemony (Storey, 2018, p. 3). Nowadays we know that popular culture provides us with easy means to reflect on what binds and what divides us, whether such forms of cultural citizenship take progressive or conservative forms (Eeken \& Hermes, 2021; Hermes, 2005). That it affords wholehearted immersion and excitement over issues that are deeply political, but quite possibly more properly belong in other realms. The opening line of this article, one of the many tweets about the Shondaland series Bridgerton for Netflix, proves this point: Bridgerton is based on a series of romance novels, one of the ultimate "pulp" genres. As a Netflix offering it has become "drama." In the hands of producer Shonda Rhimes, it also became a political vehicle to suggest that racial diversity requires only the smallest leap of the imagination. On Twitter, however, the series becomes a cause célèbre to vent outrage over historical inaccuracy: not just about whether or not the English nobility might have been a more diverse group of people than is assumed, but about its costumes and musical scores as well. An astounding wish for authoritative, historically correct storytelling seems to motivate the twitterers. The point seems lost that Bridgerton might simply be an instance of "the popular," of that which gives us energy and hope and a sense that everything might be better (and to $\mathrm{h}^{* * *}$ with historical accuracy and other norms, codes, and prescriptions). A pity really, that without the popular, we are all dancing in our riding boots (which, for the uninitiated, is truly extremely uncomfortable).

\section{Acknowledgments}

The authors wish to thank the two anonymous reviewers for their constructive remarks on an earlier version of this article.

\section{Conflict of Interests}

The authors declare no conflict of interests.

\section{References}

Ahmed, S. (1999). Phantasies of becoming the other. European Journal of Cultural Studies, 2(1), 47-63. https://doi.org/10.1177/136754949900200103 
Althusser, L. (1971). Lenin and philosophy and other essays. Monthly Review Press.

Andeweg, A. (2017). Novels as social media: How literature helped shape notions of sexual liberation. Sexuality \& Culture, 21, 343-361. https://doi.org/ 10.1007/s12119-017-9419-9

Ang, I. (1985). Watching Dallas: Soap opera and the melodramatic imagination. Methuen.

Bastos, M. T., \& Mercea, D. (2019). The Brexit botnet and user-generated hyperpartisan news. Social Science Computer Review, 37(1), 38-54. https://doi.org/ $10.1177 / 0894439317734157$

Bennett, T. (1982). James Bond as popular hero, Unit 21. In T. Bennett (Ed.), Politics, ideology and popular culture 2 (pp. 5-33). Open University Press.

Bennett, T. (1986). The politics of "the popular" and popular culture. In T. Bennett, C. Mercer, \& J. Woolacott (Eds.), Popular culture and social relations (pp. 6-21). Open University Press.

Bennett, T. (1995). The birth of the museum: History, theory, politics. Routledge.

Bennett, T. (1998). Culture: A reformer's science. SAGE.

Bennett, T. (2003). Culture and governmentality. In J. Z. Bratich, J. Packer, \& C. McCarthy (Eds.), Foucault, cultural studies, and governmentality (pp. 47-63). Suny.

Bourdieu, P. (1980). The production of belief: Contribution to an economy of symbolic goods. Media, Culture \& Society, 2(3), 261-293. https://doi.org/ $10.1177 / 016344378000200305$

Burke, P. (2009). Popular culture in early modern Europe. Routledge. (Original work published 1978)

cCCS Women's Studies Group. (Eds.). (1978). Women take issue. Hutchinson.

Clifford, J., \& Marcus, G. E. (Eds.). (1986). Writing culture: The poetics and politics of ethnography. University of California Press.

Coffey, M. K. (2003). From nation to community: Museums and the reconfiguration of Mexican society under neoliberalism. In J. Z. Bratich, J. Packer, \& C. McCarthy (Eds.), Foucault, cultural studies, and governmentality (pp. 207-242). Suny.

Curran, J. (1990). The new revisionism in mass communication research: A reappraisal. European Journal of Communication, 5(2), 135-164. https://doi.org/ 10.1177/0267323190005002002

Eeken, S., \& Hermes, J. (2021). Doctor Who, ma'am: YouTube reactions to the 2017 reveal of the new Doctor. Television \& New Media, 22(5), 1-18. https:// doi.org/10.1177/1527476419893040

Enli, G. (2017). Twitter as arena for the authentic outsider: Exploring the social media campaigns of Trump and Clinton in the 2016 US presidential election. European Journal of Communication, 32(1), 50-61. https://doi.org/10.1177/0267323116682802

Fernández Castro, J. (2017). Stuart Hall: An organic intellectual. Middle East-Topics \& Arguments, 7, 23-29. https://doi.org/10.17192/meta.2017.7.5134

Fiske, J. (1987). Television culture. Methuen.
Fiske, J., \& Hartley, J. (1978). Reading television. Methuen.

Foucault, M. (1970). The order of things: An archeology of the human sciences. Tavistock.

Foucault, M. (1972). The archaeology of knowledge. Tavistock.

Foucault, M. (1977). Discipline and punish. Tavistock.

Fox, J., \& Ralston, R. (2016). Queer identity online: Informal learning and teaching experiences of LGBTQ individuals on social media. Computers in Human Behavior, 65, 635-642. https://doi.org/10.1016/ j.chb.2016.06.009

Fredericks, E. A. [tiny_bookbot]. (2020, December 31). People griping about nonwhite actors in Bridgerton but not fussing about the Duke wearing riding boots to a ball? [Tweet]. Twitter. https://twitter.com/tiny bookbot/status/1344465298552811521?s $=20$

Fuchs, C. (2010). Labor in informational capitalism and on the internet. The Information Society, 26(3), 179-196. https://doi.org/10.1080/0197224100371 2215

Geertz, C. (1973). The interpretation of cultures. Basic books.

Gibson, M., \& Hartley, J. (1998). Forty years of cultural studies: An interview with Richard Hoggart, October 1997. International Journal of Cultural Studies, 1(1), 11-23. https://doi.org/10.1177/1367877 99800100102

Gillespie, M. (1995). Television and ethnicity. Routledge.

Gn, J. (2011). Queer simulation: The practice, performance and pleasure of cosplay, Continuum, 25(4), 583-593. https://doi.org/10.1080/10304312. 2011.582937

Gramsci, A. (1971). Selections from the prison notebooks. International publishers.

Gray, A. (1992). Video playtime: The gendering of a leisure technology. Routledge.

Grossberg, L. (1992). The affective sensibility of fandom. In L. A. Lewis (Ed.), The adoring audience: Fan culture and popular media (pp. 50-65). London.

Hall, S. (1997). The work of representation. In S. Hall (Ed.), Representation: Cultural representations and signifying practices (pp. 13-74). SAGE.

Hall, S., \& Jefferson, T. (1975). Resistance through rituals. Hutchinson.

Hall, S., Lumley, R., \& McLennan, G. (2007). Politics and ideology: Gramsci. In A. Gray, J. Campbell, M. Erickson, S. Hanson, \& H. Wood (Eds.), CCCS selected working papers (Vol. 1, pp. 278-305). Routledge. (Original work published 1977)

Hall, S., \& Whannell, G. (Eds.). (1964). The popular arts. Pantheon.

Hammersley, M., \& Atkinson, P. (1998). Ethnography: Principles in practice (3rd ed.). Routledge.

Hartley, J. (1999). Uses of television. Routledge.

Hay, J. (2003). The (neo) liberalization of the domestic sphere and the new architecture of community. In J. Z. Bratich, J. Packer, \& C. McCarthy (Eds.), Foucault, 
cultural studies, and governmentality (pp. 165-206). Suny.

Hebdige, D. (1979). Subculture: The meaning of style. Methuen.

Hermes, J. (1995). Reading women's magazines. Polity Press.

Hermes, J. (2005). Rereading popular culture. Blackwell.

Hermes, J., \& Kardolus, M. (2019). Occupying the intersection: RuPaul's celebration of meritocracy. Critical Studies in Television, 14(4), 462-467.

Hewison, R. (2014). Cultural capital: The rise and fall of Creative Britain. Verso.

Hills, M. (2002). Fan cultures. Routledge.

Jenkins, H. (2021). Who the \&\%\&\# is Henry Jenkins? Henry Jenkins. http://henryjenkins.org/aboutme html

Jenkins, H., Peters-Lazaro, G., \& Shresthova, S. (Eds.). (2020). Popular culture and the civic imagination. New York University Press.

Jensen, J. (1990). Redeeming modernity. SAGE.

King, S. J. (2003). Doing good by running well: Breast cancer, the race for the cure, and new technologies of ethical citizenship. In J. Z. Bratich, J. Packer, \& C. McCarthy (Eds.), Foucault, cultural studies, governmentality (pp. 285-301). Suny.

Littler, J. (2018). Against meritocracy: Culture, power and myths of mobility. Routledge.

Lovink, G. (2002). Dark fiber: Tracking critical internet culture. MIT Press.

Lovink, G. (2012). Networks without a cause: A critique of social media. Institute of Network Cultures.

McGuigan, J. (1992). Cultural populism. Routledge.

Miklaucic, S. (2003). God games and governmentality: Civilization II and hypermediated knowledge. In J. Z. Bratich, J. Packer, \& C. McCarthy (Eds.), Foucault, cultural studies, governmentality (pp. 317-335). Suny.

Moran, M., \& McGuigan, J. (2020). "Tory stories": Arguing for a critical cultural populism, again. European Journal of Cultural Studies, 23(6), 1005-1013.

Morley, D. (1980). The Nationwide audience: Structure and decoding. British Film Institute.

Morley, D. (1986). Family television. Comedia.

Morris, M. (1988). Banality in cultural studies. Discourse, 10(2), 3-29.

Newcomb, H., \& Hirsch, P. M. (1983). Television as a cultural forum. Quarterly Review of Film \& Video, 8(3), 45-55.
Ouellette, L. (2004). Take responsibility for yourself: Judge Judy and the neoliberal citizen. In S. Murray \& L. Ouellette (Eds.), Reality TV: Remaking television culture (pp. 231-250). New York University Press.

Packard, V. (1957). The hidden persuaders. Pocket Books.

Pariser, E. (2011). The filter bubble: What the internet is hiding from you. Penguin UK.

Radway, J. (1984). Reading the romance. University of North Carolina Press.

Seymour, R. (2016). Schadenfreude with bite. London Review of Books. https://www.Irb.co.uk/v38/n24/ richard-seymour/schadenfreude-with-bite

Skeggs, B., Thumim, N., \& Wood, H. (2008). "Oh goodness, I am watching reality TV": How methods make class in audience research. European Journal of Cultural Studies, 11(1), 5-24. https://doi.org/10.1177/ 1367549407084961

Stallybrass, A., \& White, P. (1986). The politics and poetics of transgression. Cornell University Press.

Storey, J. (2018). Cultural theory and popular culture (8th revised ed.). Routledge.

Terranova, T. (2000). Free labor: Producing culture for the digital economy. Social Text, 63(18), 33-58.

Thornton, S. (1995). Club cultures: Music, media, and subcultural capital. Polity Press.

Tufekci, Z. (2014). Engineering the public: Big data, surveillance and computational politics. First Monday, 19(7). https://doi.org/10.5210/fm.v19i7.4901

Walkerdine, V. (1986). Video replay: Families, films and fantasy. In V. Burgin, J. Donald, \& C. Kaplan (Eds.), Formations of fantasy (pp. 167-199). Methuen.

Wekker, G. (2016). White innocence: Paradoxes of colonialism and race. AUP.

Wetherell, M. (2012). Affect and emotion. SAGE.

Winlow, S., \& Hall, S. (2007). Book review: Resistance through rituals (2nd ed.). Crime, Media, Culture, 3(3), 394-397. https://doi.org/10.1177/ 17416590070030030902

Wood, H. (2017). The politics of hyperbole on Geordie Shore: Class, gender, youth and excess. European Journal of Cultural Studies, 20(1), 39-55. https://doi. org/10.1177/1367549416640552

Ytreberg, E. (2004). Formatting participation within broadcast media production. Media, Culture \& Society, 26, 677-692.

Yudice, G. (2004). The expediency of culture. Duke University Press.

\section{About the Authors}

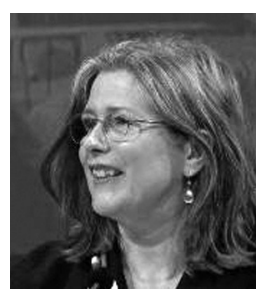

Joke Hermes (PhD) is a Professor of Media, Culture and Citizenship at Inholland University of Applied Sciences. She teaches television and cross-media culture at the University of Amsterdam and is Founding Co-Editor of the European Journal of Cultural Studies. Currently her work focuses on questions of inclusion and the creative industries, and on the development of participatory design research practice as a new format for audience research. 


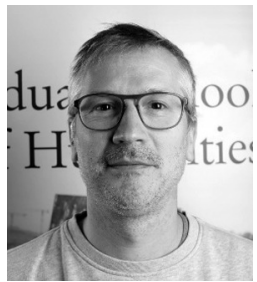

Jan Teurlings (PhD) is a Lecturer in TV and cross-media at the University of Amsterdam. His earlier work focused on how, in the demotic era, ordinary people in the media are managed by media professionals, but in recent years his work focuses on the relationship between media and transparency. 